\title{
Water Distillation Using Solar Energy System with Lauric Acid as Storage Medium
}

\author{
A. A. F. Al-Hamadani, S. K. Shukla* \\ Department of Mechanical Engineering, I.T. B.H.U ,Varanasi, UP, India
}

\begin{abstract}
An experimental investigation on a solar still with lauric acid as phase change material (PCM) is carried out to examine the effect of both the mass of PCM and basin water on the daily distillate productivity and efficiency of the system under outdoor condition. Basic energy balance equations are written to predict the water and glass temperatures, daily distillate productivity and instantaneous efficiency of the single slope solar distillation system with PCM. It is found that the higher mass of PCM with lower mass of water in solar still basin significantly increases the daily productivity and the efficiency. Therefore, the distillate productivity at night and on day for solar still with PCM increased by $127 \%$ and $30-35 \%$ respectively than without PCM one. Shukla et al. approach of the use of inner glass cover temperature for productivity prediction which has also been investigated, and the prediction shows relatively better agreement with the experimental data than outer glass cover temperature.
\end{abstract}

Keywords Water Distillation, Solar Energy, Phase Change Material, Efficiency, Heat Transfer Coefficients

\section{Introduction}

Portable water is indispensible for life and its scarcity is growing across the world, particularly in dry regions, such as deserts and modern industrial areas. The similar problem exists in remote areas and islands where fresh water supply through any transportation means is expensive. On the other hand, seawater exists in plenty but it necessitates the removal of the salinity with additional expense of energy which is another scarce resource. Survey reveals that approximately $79 \%$ of available water is salty, $20 \%$ is brackish, and only $1 \%$ is fresh. Therefore, solar energy being free and in abundance is being utilized for the purpose of desalination of brackish water to produce drinking water[1,2].

Extensive research work on parametric studies and methods to improve the productivity of passive solar stills has been reported in literature. Passive solar stills directly use solar energy to produce distillate water, and are self-operating, simple in construction and relatively free of maintenance[3] whereas, active stills comprise of energy concentrator to add more energy to the system for enhancing the distillate productivity. The double slope solar still did not prove superior to single slope solar still[4,5]. However, single slope solar still with a condenser in the shaded region slopped increases the still efficiency by $45 \%$ [6], bla-

* Corresponding author:

skshukla.mec@itbhu.ac.in (S. K. Shukla)

Email address: alirudhaengmec@gmail.com (A. A. F. Al-Hamadani)

Published online at http://journal.sapub.org/ijee

Copyright (C) 2011 Scientific \& Academic Publishing. All Rights Reserved ck dye injection in basin water enhance the productivity by $29 \%$ [7], the maximum of the annual productivity attained when the condensing glass cover inclination is equal to the latitude of the place[8,9] were found that a lower water depth gives better efficiency, they were dependent on instantaneous gain and loss efficiency curves to give a better understanding of the performance of solar stills.

Yet, the solar stills have not found commercial utility due to low productivity, and the reason associates to the heat loss to the surroundings[10-12] Options like use of energy storage system for post sunset operation are being investigated involving phase change materials (PCM) that exploit latent heat capacity[13] to absorb the large amount of energy.

They $[14,15]$ were used phase change material (PCM) as a energy storage medium to study the performance of stepped solar still and a single basin solar still, respectively. The productivity of solar still with PCM storage medium were found to increase during post sunset operation, which occurred due to higher temperature difference between water and glass cover at relatively lower ambient temperature. They[15] analysed the transient performance of a single slope solar still with stearic acid as a storage material and observed increased productivity with increasing the mass of the PCM, however, they mentioned that the work on solar still with PCM storage medium is still scanty. In the present study, performance of a single slope solar still with Lauric acid (99\% purity) as PCM has been investigated for various masses under outdoor conditions at day in summer season. The energy balance equations for different components of the still during charging and discharging modes have been 
written and solved analytically. Calculations have been carried out for daily productivity and instantaneous efficiency of the still.

\section{Experimental Procedure}

A photograph of both the solar stills, with and without phase change material (PCM) as a storage medium, is given in Figure. 1. The basin, fabricated from a black painted mild steel sheet of thickness $2 \mathrm{~mm}$, has an area of $1 \mathrm{~m}^{2}$ each.

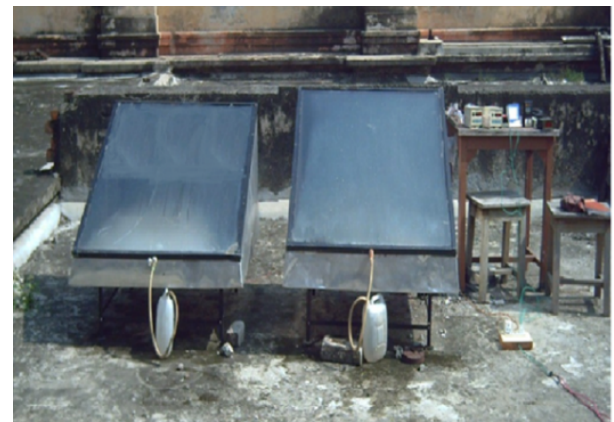

Figure 1. A photograph of the conventional solar still and solar still with (right) and without PCM (left).

A vertical gap $(0.05 \mathrm{~m})$ beneath the horizontal portion of the basin liner is provided to upload and/or unload the PCM through a pipe which takes care of the volumetric expansion of the melting PCM as well. The operational and melting temperature of PCM, in fact, governs the applicability of different types of phase change materials. The lauric acid relates to the class of fatty acids that have superior properties such as melting congruency, good chemical stability and non-toxicity, good thermal reliability[16,17]over many other PCMs.

Table 1. Thermo-physical properties of Lauric acid

\begin{tabular}{|c|c|c|}
\hline S.No. & Properties & Value \\
\hline 1 & Melting point & $40-43.9^{\circ} \mathrm{C}$ \\
\hline 2 & Latent heat of fusion & $180 \mathrm{~kJ} / \mathrm{kg}$ \\
\hline 3 & Thermal conductivity & $0.16 \mathrm{Wm}^{-1}{ }^{\circ} \mathrm{C}^{-1}$ \\
\hline & Specific heat & $2.1 \mathrm{kJkg}^{-1} \mathrm{oC}^{-1}$ \\
3 & solid at $25^{\circ} \mathrm{C}$ & $\mathrm{kJg}^{-1} \mathrm{oC}^{-1}$ \\
& liquid at $44^{\circ} \mathrm{C}$ & $1007 \mathrm{~kg} / \mathrm{m} 3$ \\
& Density solid liquid & $862 \mathrm{~kg} / \mathrm{m} 3$ \\
\hline 5
\end{tabular}

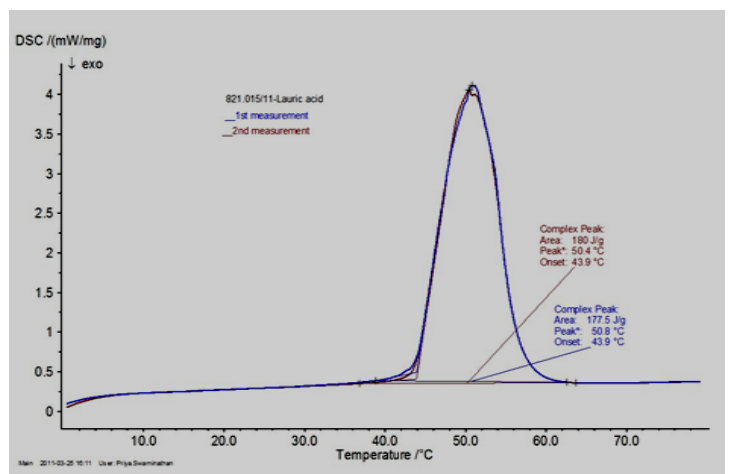

Figure 2. DSC curve for melting temperature and heat of fusion for Lauric acid.

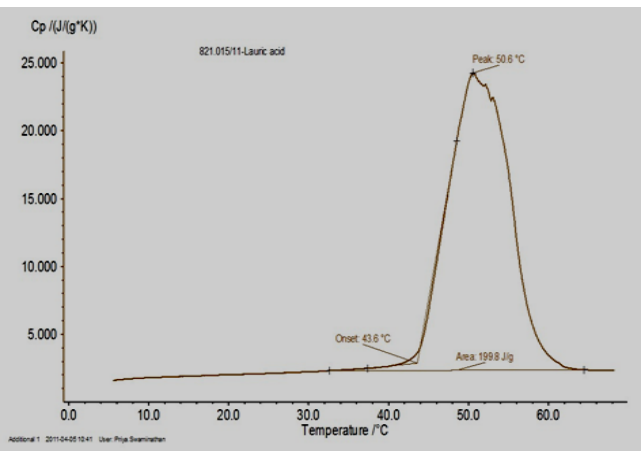

Figure 3. DSC curve for specific heat of Lauric acid

Therefore, lauric acid has been used as a latent heat storage material due to its low cost and easy availability. Table 1 summarizes the thermo-physical properties of lauric ac$\operatorname{id}[18,19]$ used in the experimentation.

The measurement of property of PCM was done in Netzsch Technologies India Pvt Ltd. By using the differential scanning calorimetry (DSC) technique as revealed in Figures 2 and 3.

The bottom and sides of the basin are insulated by $5 \mathrm{~cm}$ thick layer of rock wool contained in an aluminium tray. The top cover of the still is made up of $4 \mathrm{~mm}$ thick window glass which inclines at an angle of $25^{\circ}$ with horizontal, and has an average transmissivity $(\tau)$ of value 0.88 . A $U$-shaped channel is used to collect the condensate from the lower edge of glass cover and carry it to storage. Figure. 4 shows the operational system with all the peripherals.

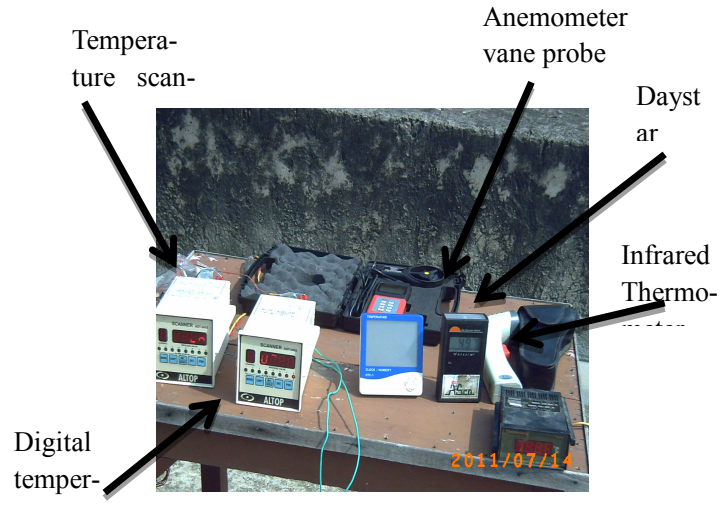

Figure 4. Photograph of the measurement instruments.

A temperature scanner (Altop Industries ltd, Sn.1005164, model ADT 5003) with resolution $0.1^{\circ} \mathrm{C}$ and $\mathrm{HTC}$ DT-8811Infrared thermometer range: $-20^{\circ} \mathrm{C}-450^{\circ} \mathrm{C}$ Spectral response: $6-14 \mu \mathrm{m} \mathrm{CE}$ ASCO products had been used to record the temperature with k-type thermocouples in solar stills. The solar radiation measure by using the daystar meter Watts/m2 ASCO products, the wind speed was observed by HTC Instruments AVM-07 Anemometer vane probe CE.

The variation of the typical observed ambient temperature and calculated solar radiation have been shown in Figures 5 and 6 . The experimental observation were taken from $7 \mathrm{am}$ (shown as 0:00 hrs) to $6 \mathrm{pm}$ (shown as 10:00 hrs.) The different water masses, i.e., 30,40 , and $50 \mathrm{~kg}$ and PCM masses, i.e., 10, 20, and $30 \mathrm{~kg}$ have been used. The solar 
radiation was varied from zero to $815 \mathrm{~W} / \mathrm{m} 2$ in summer day.

\section{Thermal Analysis}

\subsection{Mathematical Models}

Assumptions have been made:-

1.The solar still distillation unit is vapor-leakage proof.

2.The conduction heat transfer mode between PCM and basin liner.

3.The temperature gradient through PCM negligible.

4.The experiments were carried out under atmospheric pressure.

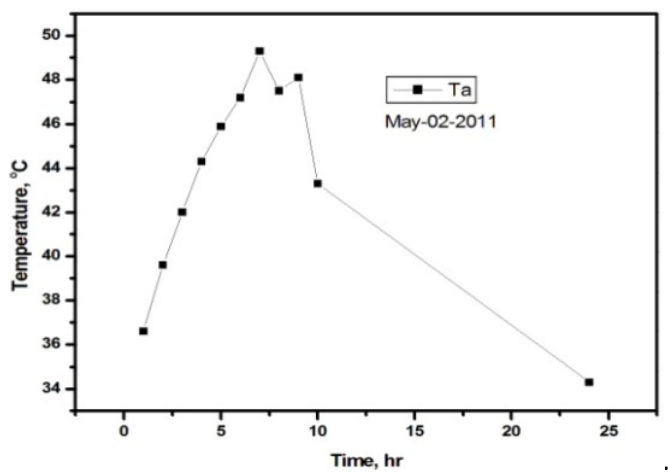

Figure 5. Variation of ambient temperature to solar still for 24 hour on May-02-2011.

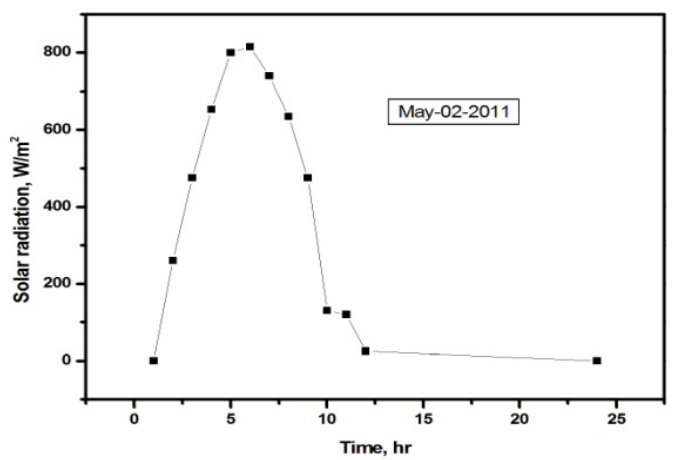

Figure 6. Variation of solar radiation to solar still with variation for 24 hour on May-02-2011.

\subsubsection{The still with the PCM charging mode}

Energy balance of the glass cover of the inner surface

$$
\alpha_{\mathrm{g}}^{\prime} \mathrm{I}(\mathrm{t})+\mathrm{h}_{1}\left(\mathrm{~T}_{\mathrm{w}}-\mathrm{T}_{\text {gin }}\right)=\mathrm{k}_{\mathrm{g}} / \mathrm{L}_{\mathrm{g}}\left(\mathrm{T}_{\text {gin }}-\mathrm{T}_{\mathrm{go}}\right)
$$

Energy balance of the glass cover of the outer surface

$$
\mathrm{k}_{\mathrm{g}} / \mathrm{L}_{\mathrm{g}}\left(\mathrm{T}_{\mathrm{gin}}-\mathrm{T}_{\mathrm{go}}\right)=\mathrm{h}_{2}\left(\mathrm{~T}_{\mathrm{go}}-\mathrm{T}_{\mathrm{a}}\right)
$$

Energy balance of the water mass

$$
\alpha_{w}^{\prime} I(t)+h_{3}\left(T_{b}-T_{w}\right)=M_{w} C_{w} d T_{w} / d t+h_{1}\left(T_{w}-T_{\text {gin }}\right)
$$

Energy balance of the basin liner

$$
\alpha_{b}^{\prime} I(t)=h_{3}\left(T_{b}-T_{w}\right)+h_{b c}\left(T_{b}-T_{p c m}\right)
$$

Energy balance of the phase change material PCM

$\mathrm{h}_{\mathrm{bc}}\left(\mathrm{T}_{\mathrm{b}}-\mathrm{T}_{\mathrm{pcm}}\right)=\left(\mathrm{M}_{\mathrm{equ}} / \mathrm{A}_{\mathrm{b}}\right)\left(\mathrm{dT}_{\mathrm{pcm}} / \mathrm{dt}\right)+\mathrm{h}_{\mathrm{b}}\left(\mathrm{T}_{\mathrm{pcm}}-\mathrm{T}_{\mathrm{a}}\right)$

Where $h_{b}=k_{\text {ins }} / \mathrm{x}_{\text {ins }}$ is the back loss coefficient and Mequ is the equivalent heat capacity of the PCM, which was expressed in (Abdulhaiy 2005) and (El-Sebaii, Al-Ghamdi et al. 2009).

$$
\begin{aligned}
& M_{\text {equ }}=m_{\text {pcm }} C_{s, p c m} \text { for } T_{-} b<T_{-} m t, \\
& M_{\text {equ }}=m_{\text {pcm }} L_{s, p c m} \text { for } T_{-} b<T_{-} m t+\delta, \\
& M_{\text {equ }}=m_{\text {pcm }} C_{l, p c m} \text { for } T_{b}>T_{m t} .
\end{aligned}
$$

The resultant was $T_{g o}, T_{\text {gin }}$ and $T_{b}$ from eqs. (1), (2) and (4):

$$
\begin{gathered}
\mathrm{T}_{\mathrm{go}}=\left(\mathrm{k}_{\mathrm{g}} / \mathrm{L}_{\mathrm{g}} \mathrm{T}_{\mathrm{gin}}+\mathrm{h}_{2} \mathrm{Ta}\right) /\left(\mathrm{h}_{2}+\mathrm{k}_{\mathrm{g}} / \mathrm{L}_{\mathrm{g}}\right) \\
\mathrm{T}_{\mathrm{gin}}=\left(\alpha_{\mathrm{g}}^{\prime} \mathrm{I}(\mathrm{t})+\mathrm{h}_{1} \mathrm{~T}_{\mathrm{w}}+\mathrm{U}_{\mathrm{ga}} \mathrm{Ta}\right) /\left(\mathrm{U}_{\mathrm{ga}}+\mathrm{h}_{1}\right) \\
\mathrm{T}_{\mathrm{b}}=\left(\alpha_{\mathrm{b}}^{\prime} \mathrm{I}(\mathrm{t})+\mathrm{h}_{3} \mathrm{~T}_{\mathrm{w}}+\mathrm{h}_{\mathrm{bc}} \mathrm{T}_{\mathrm{pcm}}\right) /\left(\mathrm{h}_{3}+\mathrm{h}_{\mathrm{b}}\right)
\end{gathered}
$$

We got eq (9) by placing the value of eq (7) and eq (8) in the variants of the eq(3)

$$
\mathrm{dT}_{\mathrm{w}} / \mathrm{dt}+\mathrm{a}_{\mathrm{c}} \mathrm{T}_{\mathrm{w}}=\mathrm{fc}(\mathrm{t})
$$

$\mathrm{Eq}(6)$ was solved by using the integral factor with the boundary condition, when $\mathrm{t}=0$ that led to $\mathrm{Tw}=$ Two thus :

$$
\mathrm{T}_{\mathrm{w}}=\mathrm{fc}(\mathrm{t}) / \mathrm{a}_{\mathrm{c}}\left[1-\exp \left(-\mathrm{a}_{\mathrm{c}} \mathrm{t}\right)\right]+\mathrm{T}_{\mathrm{wo}} \exp \left(-\mathrm{a}_{\mathrm{c}} \mathrm{t}\right)
$$

To get Tpcm from eq (11) and eq (8)

$$
\mathrm{T}_{\mathrm{pcm}}=\mathrm{fc} 1(\mathrm{t}) / \mathrm{a}_{\mathrm{cl}}\left[1-\exp \left(-\mathrm{a}_{\mathrm{c} 1} \mathrm{t}\right)\right]+\mathrm{T}_{\mathrm{pcm}} \exp \left(-\mathrm{a}_{\mathrm{c} 1} \mathrm{t}\right)
$$

\subsubsection{The still with the PCM discharging mode}

The energy balance equation for the PCM at the interval time $\Delta \mathrm{t}$ may be written as:

$$
\begin{aligned}
& \quad \mathrm{m}_{\mathrm{pcm}} \mathrm{L}_{\mathrm{pcm}} / \mathrm{A}_{\mathrm{b}} \Delta \mathrm{t}=\mathrm{h}_{\mathrm{bd}}\left(\mathrm{T}_{\mathrm{pcm}}-\mathrm{T}_{\mathrm{b}}\right)+\mathrm{h}_{\mathrm{b}}\left(\mathrm{T}_{\mathrm{pcm}}-\mathrm{T}_{\mathrm{a}}\right) \\
& \text { For } \mathrm{T}_{\mathrm{pcm}}=\mathrm{T}_{\mathrm{mt}} \\
& \mathrm{h}_{\mathrm{bd}}\left(\mathrm{T}_{\mathrm{pcm}}-\mathrm{T}_{\mathrm{b}}\right)+\mathrm{h}_{\mathrm{b}}\left(\mathrm{T}_{\mathrm{pcm}}-\mathrm{T}_{\mathrm{a}}\right)=\left(\mathrm{M}_{\mathrm{equ}} / \mathrm{A}_{\mathrm{b}}\right)\left(\mathrm{dT}_{\mathrm{pcm}} / \mathrm{dt}\right) \\
& \text { For } \mathrm{T}_{\mathrm{pcm}} \neq \mathrm{T}_{\mathrm{mt}} \\
& \text { where } \mathrm{M}_{\mathrm{equ}}=\mathrm{m}_{\mathrm{pcm}} \mathrm{C}_{\mathrm{l}, \mathrm{pcm}} \text { for } \mathrm{T}_{\mathrm{pcm}}>\mathrm{T}_{\mathrm{mt}}, \\
& \mathrm{M}_{\text {equ }}=\mathrm{m}_{\mathrm{pcm}} \mathrm{C}_{\mathrm{s}, \mathrm{pcm}} \text { for } \mathrm{T}_{\mathrm{pcm}}<\mathrm{T}_{\mathrm{mt}},
\end{aligned}
$$

$\mathrm{h}_{\mathrm{bd}}=\mathrm{k}_{\mathrm{pcm}} / \mathrm{x}_{\mathrm{pcm}}$ that is the conductive heat transfer coefficient from the PCM to the basin liner.

Energy balance of the glass cover's inner surface

$$
\text { h_1 (Tw- Tgin ) =kg/Lg (Tgin- Tgo) }
$$

Energy balance of the glass cover's outer surface $\mathrm{kg} / \mathrm{Lg}($ Tgin- Tgo $)=\mathrm{h} 2$ (Tgo- Ta)

Energy balance of the water mass

$$
\text { h3 }(\mathrm{Tb}-\mathrm{Tw})=\mathrm{Mw} \mathrm{Cw} \mathrm{dTw} / \mathrm{dt}+\mathrm{h} 1 \text { (Tw - Tgin) }
$$

Energy balance of the basin liner

The Tgo resultant from eq(15)

$$
\text { h3 }(\mathrm{Tb}-\mathrm{Tw})=\text { hbd }(\mathrm{Tpcm}-\mathrm{Tb})
$$

$$
\begin{gathered}
\mathrm{Tgo}=(\mathrm{kg} / \mathrm{Lg} \text { Tgin }+\mathrm{h} 2 \mathrm{Ta}) /(\mathrm{h} 2+\mathrm{kg} / \mathrm{Lg}) \\
\text { Tgin }=(\mathrm{h} 1 \mathrm{Tw}+\mathrm{Uga} \mathrm{Ta}) /(\mathrm{Uga}+\mathrm{h} 1) \\
\mathrm{Tb}=(\mathrm{h} 3 \mathrm{Tw}+\mathrm{hbd} \mathrm{Tpcm}) /(\mathrm{h} 3+\mathrm{hbd}) \\
\mathrm{dTw} / \mathrm{dt}+\mathrm{ad} \mathrm{Tw}=\mathrm{fcd}(\mathrm{t})
\end{gathered}
$$

The resultant of the eq (21) with using of the boundary condition, when $\mathrm{t}=0$ that led to $\mathrm{Tw}=\mathrm{Two}$ thus:

$$
\mathrm{Tw}=\mathrm{fd}(\mathrm{t}) / \mathrm{ad}[1-\exp (-\mathrm{ad} \mathrm{t})]+\text { Two } \exp (-\mathrm{ad} \mathrm{t})
$$

The $\mathrm{Tpcm}$ was resulted by placing $\mathrm{Tb}$ (eq. 20 ) which was contained in eq(16) after applying the integral method

$\mathrm{Tpcm}=\mathrm{fd} 1(\mathrm{t}) / \mathrm{ad} 1[1-\exp (-\operatorname{ad} 1 \mathrm{t})]+\mathrm{Tpcm} \exp (-\operatorname{ad} 1 \mathrm{t})(23)$

\section{Productivity and Efficiency of the Solar Still}

The hourly and daily productivity of solar still is: mewh=hew $($ Tw- Tgin $) / \gamma$ Mewd $=\sum \_24 \mathrm{hr}$ mewh

The instantaneous efficiency of the solar still is: $\eta \mathrm{i}=$ hew $(\mathrm{Tw}-\mathrm{Tgin}) /(\mathrm{I}(\mathrm{t}))^{*} 100 \%$ 


\section{Numerical Computation}

Two $\mathrm{C}$ language programs were developed to find the predicted theoretical values for equations(1-26), first one had been to calculate parameters $\mathrm{c}$ and $\mathrm{n}$ for equation (A-3) appendix A, by using of Tw and Tgin observed data, then these values it used with the second developed program to calculate the productivity of solar still with and without PCM. The programme executed by using parameter design of solar still with and without PCM as shown in Table 2.

Table 2. Parameter design of solar still with and without PCM

\begin{tabular}{|c|c|c|c|}
\hline parameter & Values & parameter & Values \\
\hline $\mathrm{A}_{\mathrm{b}}$ & $1 \mathrm{~m}^{2}$ & $\varepsilon_{\mathrm{g}}$ & 0.95 \\
\hline $\mathrm{A}_{\mathrm{g}}$ & $1.1 \mathrm{~m}^{2}$ & $\varepsilon_{\mathrm{W}}$ & 0.95 \\
\hline$\alpha_{\mathrm{b}}$ & 0.95 & $\mathrm{mw}$ & $30-50 \mathrm{~kg}$ \\
\hline$\alpha_{\mathrm{g}}$ & 0.05 & $\mathrm{mpcm}$ & $10-30 \mathrm{~kg}$ \\
\hline$\alpha_{\mathrm{w}}$ & 0.05 & $\sigma$ & $5.67 \mathrm{e}-8 \mathrm{~W} / \mathrm{m}^{2}{ }^{\circ} \mathrm{K}^{4}$ \\
\hline $\mathrm{R}_{\mathrm{g}}$ & 0.05 & $\mathrm{~L}_{\text {ins }}$ & $0.05 \mathrm{~m}$ \\
\hline $\mathrm{h}_{2}$ & $5.7+3.8 \mathrm{v}$ & $\mathrm{L}_{\mathrm{b}}$ & $0.002 \mathrm{~m}$ \\
\hline $\mathrm{K}_{\mathrm{g}}$ & $0.78 \mathrm{~W} / \mathrm{m}^{2}{ }^{\circ} \mathrm{K}^{2}$ & $\mathrm{k}_{\mathrm{b}}$ & $43 \mathrm{~W} / \mathrm{m}^{2}{ }^{\circ} \mathrm{K}^{2}$ \\
\hline $\mathrm{L}_{\mathrm{g}}$ & $0.004 \mathrm{~m}$ & $\mathrm{k}_{\text {ins }}$ & $0.04 \mathrm{~W} / \mathrm{m}^{2} \mathrm{~K}^{2}$ \\
\hline $\mathrm{R}_{\mathrm{w}}$ & 0.05 & & \\
\hline
\end{tabular}

\section{Results and Discussion}

The experimentation started every day at 7:00 AM, and the temperatures of ambience vapor in vicinity of glass, at outer and inner surfaces of glass cover, basin liner, stored water and PCM were recorded at an interval of one hour till 6:00 P.M. in the evening. Simultaneously, the values of solar radiation, and distillate productivity were also recorded. Figure 7 for solar still without PCM at summer day shows that the temperatures of basin water, vapor of vicinity, outer and inner surfaces of glass cover, basin liner, stored water and the temperature increased with increased $(\mathrm{I}(\mathrm{t})$. Ab) and decreases thereafter following the similar trend to that of solar radiation given in Figure 7 until 6:00 PM.

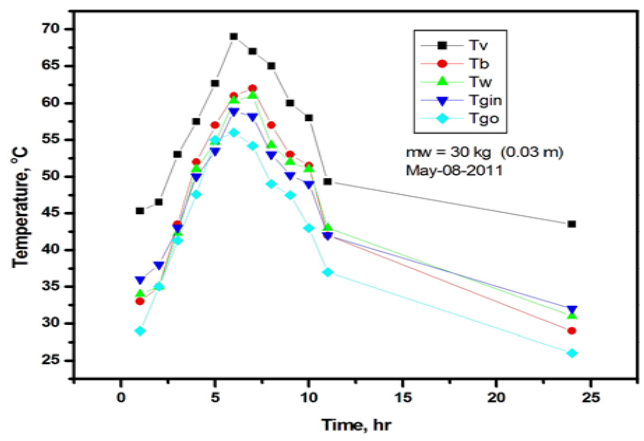

Figure 7. Variation of temperature with time for solar still without PCM at summmer day.

The latent energy stored in the lauric acid keeps the system operational during the night to deliver distillate productivity. However, the decreasing trend of all above temperatures shows that the quantity of distillate productivity reduces (see Figures 8-9) due to lower difference in the operating temperature of glass cover and ambience that continues till next day morning. The productivity due to solar still without PCM has also been shown in Figure 8 for the comparative purpose.

It is observed that the PCM enhances the productivity of the system by $30 \%$ due to PCM being acting as heat source under discharge mode during night.

Further, the productivity, for given mass of water in the basin of the solar still with PCM has also been plotted for daytime and night hours, separately to understand the operational characteristics of the system with time. Figure 9 (A) shows that the productivity decreases with the increase in water mass during daytime, and it is due to the fact that higher quantity of water relatively needs more energy to raise its temperature before being evaporated. However, the productivity increases with the increasing water mass and PCM mass during night hours (see Figure 9 B) due to relatively larger storage of energy in PCM as latent heat and sensible heat in higher water mass, thus for $30 \mathrm{~kg}$ PCM the percentage of enhancement of productivity was $127 \%$ compare with solar still without PCM.

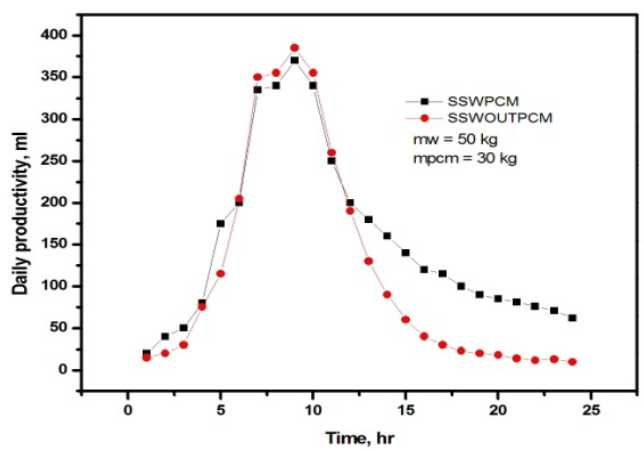

Figure 8. Variation of daily productivity for solar still with and without PCM for summer day.

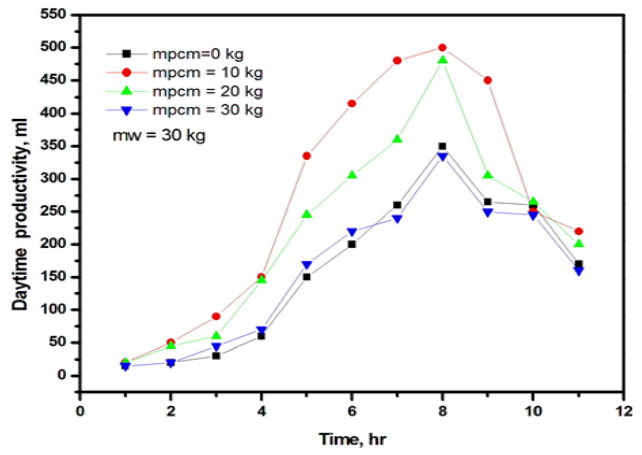

Figure 9A. Variation of daytime productivity due to solar still with and without PCM.

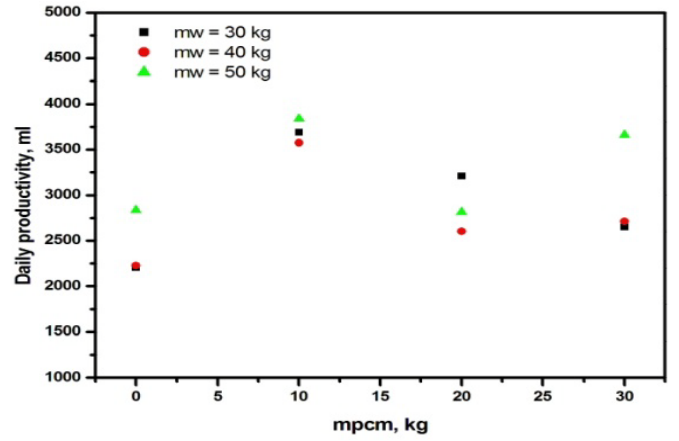

Figure 9B. Variation of on night productivity due to solar still with and without PCM for summer day. 
The variation of total distillate productivity with time, for different water masses, has been plotted for $24 \mathrm{hrs}$ duration (see Figure 10). The decreasing trend of the curve in Figure 10 reveals that the thicker water depth in solar still basin yields lower distillate productivity over 24 hours, and the reason relates to the conversion of major portion of energy to sensible heat due to higher heat capacity of water mass. Further the quantity of the solar radiation is very important reason to increase the day time productivity that it has been explained in Table 3.In this table the solar radiation for $20 \mathrm{~kg}$ PCM was lower quantity than $10 \mathrm{~kg}$, therefore $10 \mathrm{~kg}$ of PCM was given more productivity, other reason the $10 \mathrm{~kg}$ absorbed low heat during day.

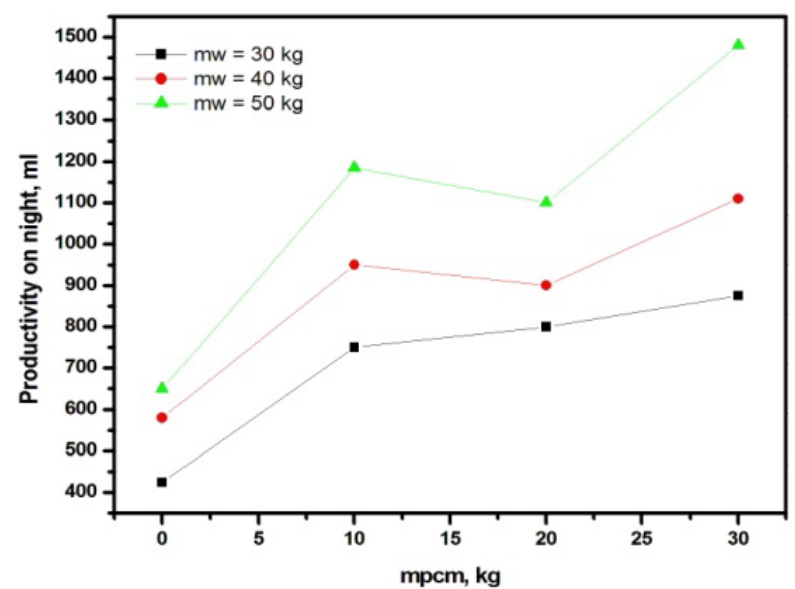

Figure 10. Variation of daily productivity due to solar still with and without PCM.

Figures $9 \mathrm{~A}$ and $\mathrm{B}$ also show that the productivity of solar still for different water masses during day and night hours, respectively. It is observed that the trend of the curves for three different water masses remains diminishing during day hours and converse during night.

It is interesting to note that the lower water mass in solar still with PCM yields more distillate productivity during day hours than that due to higher water mass (see Figure 9 A), whereas, the higher water mass in solar still basin gives relatively higher productivity during night hours.

Table 3. the day time productivity and solar radiation for 10 and $20 \mathrm{~kg}$ of PCM

\begin{tabular}{|c|c|c|}
\hline Masses $\mathrm{kg}$ & soalr radiation $\mathrm{W} / \mathrm{m}^{2} /$ day & Pdt Ml/day \\
\hline $\begin{array}{c}\mathrm{mw}=40 \\
\mathrm{mpcm}=10\end{array}$ & 5368 & 2625 \\
\hline $\begin{array}{c}\mathrm{mw}=40 \\
\mathrm{mpcm}=20\end{array}$ & 4876 & 1703 \\
\hline
\end{tabular}

The reason lies in the fact that the lower heat capacity of thinner water depth during day hours allows more energy to be utilized for evaporation purpose whereas the system with thicker water depth stored relatively more energy to yield higher productivity during night hours.

The variation of temperature for solar still with PCM is shown in Figure 11 for 24 hours. However, the difference in the insulation temperature in relation to that of still without PCM is more significant for solar still having higher mass of
PCM (see Figures 12A, B and C).

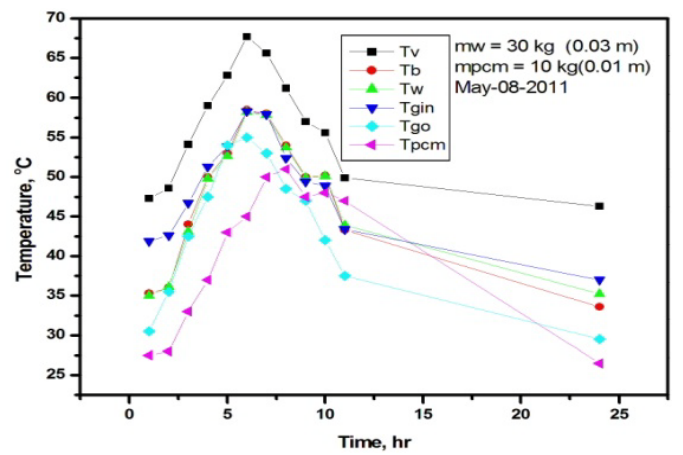

Figure 11. Variation of temperature for solar still with PCM.

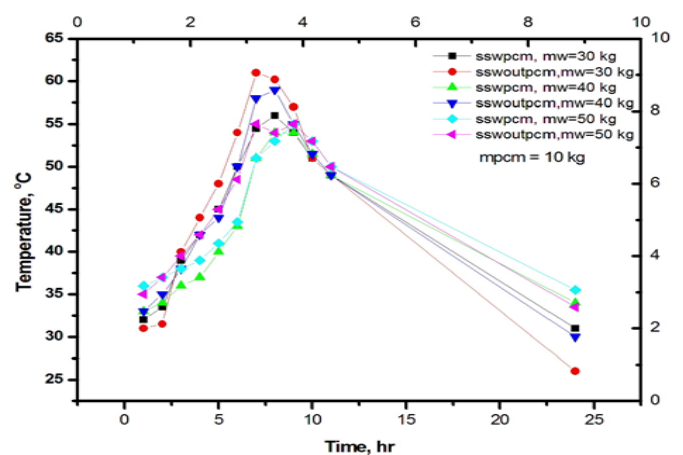

Figure 12A. Variation of insulation temperature for solar still with and without PCM for all water mass at $\mathrm{mpcm}=10 \mathrm{~kg}$.

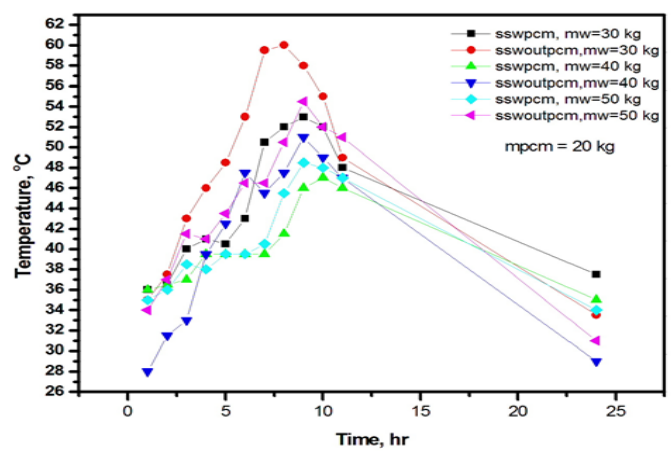

Figure 12B. Variation of insulation temperature for solar still with and without PCM for all water mass at $\mathrm{mpcm}=20 \mathrm{~kg}$.

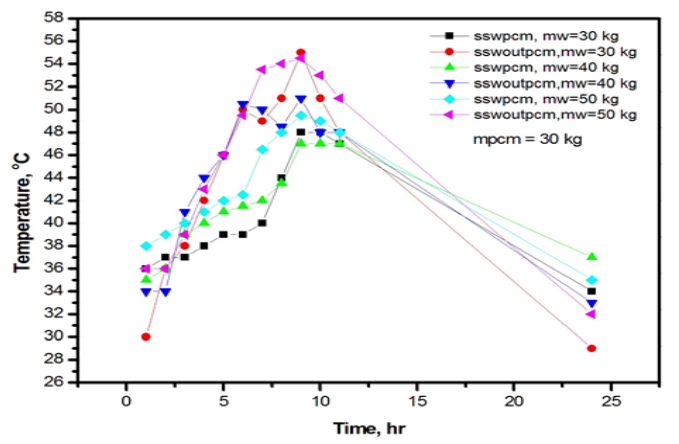

Figure 12C. Variation of insulation temperature for solar still with and without PCM for all water mass at $\mathrm{mpcm}=30 \mathrm{~kg}$.

The daily productivity for a given water mass for three different masses of PCM has been shown in Figure 13. It is observed that the overall productivity does not change significantly for 24 hours time but the productivities day and 
night at differ significantly as revealed by Figure 6 plotted for a given mass of PCM. The productivity of the solar still without PCM has also been compared see Figure 14 with the data of $[4,9]$. The observed data show the similar trend, however, the reason for the difference in the productivity may be attributed to the difference in the climatic conditions of two cities of INDIA: Varanasi and NewDelhi.

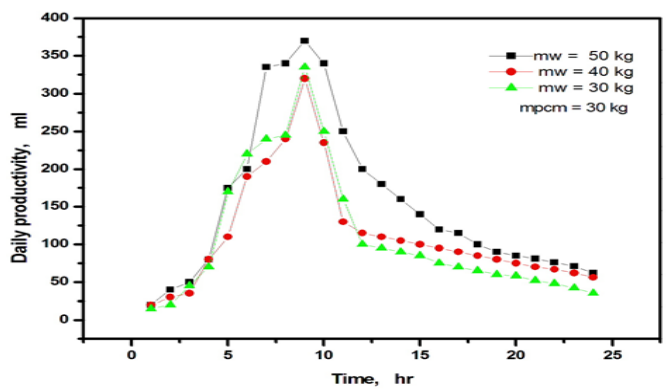

Figure 13. Variation of hourly productivity due to solar still with PCM at May 2011.

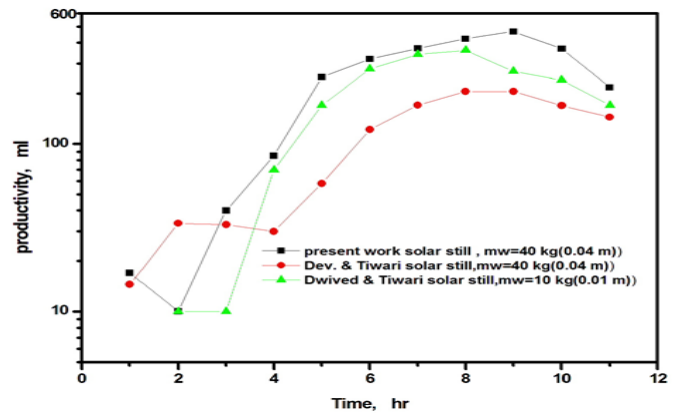

Figure 14. Variation daily productivity for different type of solar still at same solar radiation.

Further, the energy balance equations were applied to predict the distillate productivity due to stills, with and without PCM, for the comparison with the observed data. Figures 15 and 16 show that the predictions due to analytical method reasonably agree with the observed data and deviation falls within $\pm 28 \%$ for solar still without PCM, and \pm 31,31 and $20 \%$ for solar still with PCM mass of $10 \mathrm{~kg}$ with water mass of 30,40 and $50 \mathrm{~kg}$, respectively. The increased/ decreased deviation, i.e., $32,35,26 \%$ and 24,30 and $26 \%$ between predicted and observed data were found for the solar still at other two different masses of PCM for water masses 30,40 and 50 respectively.

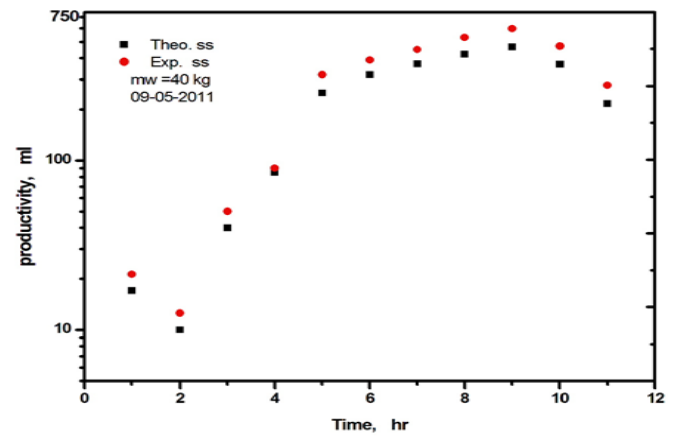

Figure 15. Comparison of predicted and observed production for solar still without PCM.

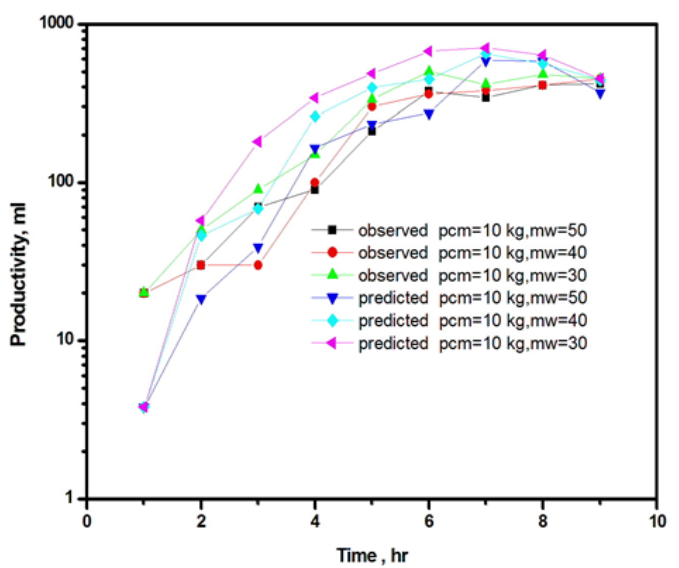

Figure 16. Comparison of predicted and observed production for solar still with PCM of pcm $=10 \mathrm{~kg}$.

The variation of the instantaneous efficiency for solar stills, with and without PCM, has also been plotted in Figure 17. It is observed that the instantaneous efficiency for solar still with PCM is always higher than that due to traditional still; however, the increasing trend of both the curves with time indicates that the instantaneous efficiency keeps increasing due to increased temperature difference between basin water and ambience.

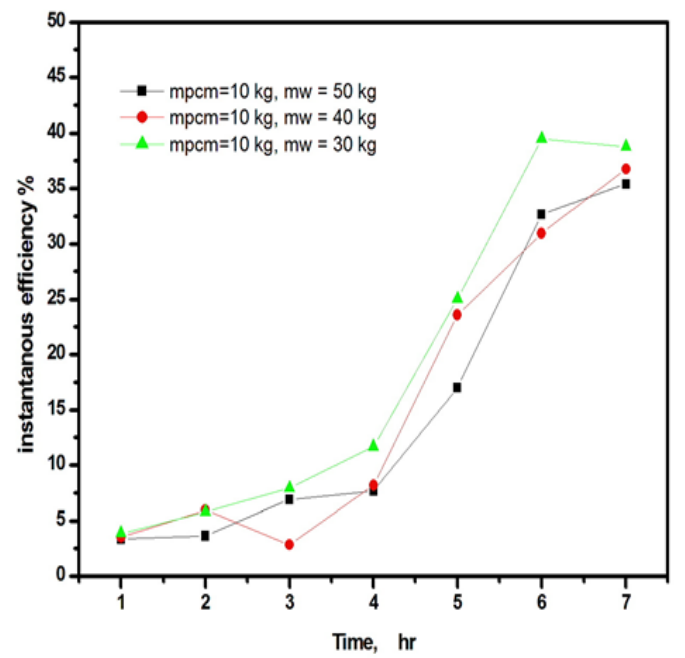

Figure 17. Variation of instantaneous efficiency for sswpcm when $\mathrm{mpcm}=10 \mathrm{~kg}$.

\section{Conclusions}

The integrated PCM with conventional solar still will increase enhancement productivity $30-35 \%$.

1. Reduce the loss of heat to surrounding when use sswpem.

2. By considering the inner glass cover temperature there is reasonable agreement between the experimental and predicted theoretical

3. It was found that the highest productivity rate is the least water depth.

4. The productivity on night increased significantly with increased PCM. 
5. The productivity of observed solar still give good pcm agreement with another observed work[4].

\begin{tabular}{|c|c|}
\hline \multicolumn{2}{|c|}{ Nomenclature } \\
\hline A & Area, $\mathrm{m}^{2}$ \\
\hline$C_{p}$ & Specific heat, $\mathrm{J} / \mathrm{kg} \mathrm{K}$ \\
\hline$d t$ & Time interval, s \\
\hline$G \boldsymbol{r}$ & Grashof number \\
\hline$h$ & Heat transfer coefficient, $\mathrm{W} / \mathrm{m}^{2} \mathrm{~K}$ \\
\hline$h c w$ & $\begin{array}{l}\text { convective heat transfer coefficient from water } \\
\text { surface to the glass cover, } \mathrm{W} / \mathrm{m}^{2} \mathrm{~K}\end{array}$ \\
\hline hew & $\begin{array}{l}\text { evaporative heat transfer coefficient from water } \\
\text { surface to the glass cover, } \mathrm{W} / \mathrm{m}^{2} \mathrm{~K}\end{array}$ \\
\hline$h r w$ & $\begin{array}{l}\text { radiative heat transfer coefficient from water } \\
\text { surface to the glass cover, } \mathrm{W} / \mathrm{m}^{2} \mathrm{~K}\end{array}$ \\
\hline$h_{1}$ & $\begin{array}{l}\text { Total heat transfer coefficient from water to glass } \\
\text { cover, } \mathrm{W} / \mathrm{m}^{2}{ }^{\circ} \mathrm{K}\end{array}$ \\
\hline $\boldsymbol{h}_{2}$ & $\begin{array}{l}\text { Convective heat transfer coefficient from glass to } \\
\text { ambient, } \mathrm{W} / \mathrm{m}^{2} \mathrm{~K}\end{array}$ \\
\hline$h_{3}$ & $\begin{array}{l}\text { Convective heat transfer coefficient from basin } \\
\text { liner to water, } \mathrm{W} / \mathrm{m}^{2} \mathrm{~K}\end{array}$ \\
\hline$i$ & current, ampere \\
\hline$I(t)$ & Solar flux on an inclined collector, $\mathrm{W} / \mathrm{m}^{2}$ \\
\hline$m$ & Mass, $\mathrm{kg}$ \\
\hline mew & Productivity, $\mathrm{ml} / \mathrm{m}^{2} \mathrm{hr}$ \\
\hline $\boldsymbol{P}$ & Partial pressure, $\mathrm{N} / \mathrm{m}^{2}$ \\
\hline $\operatorname{Pr}$ & Prandtl number \\
\hline$q$ & Heat transfer, $\mathrm{W} / \mathrm{m}^{2}$ \\
\hline Ra & Rayleigh number \\
\hline$T$ & Temperature, ${ }^{\circ} \mathrm{C}$ \\
\hline $\boldsymbol{U}_{g a}$ & $\begin{array}{l}\text { Overall heat transfer coefficient from inner glass } \\
\text { to ambient, } \mathrm{W} / \mathrm{m}^{2}\end{array}$ \\
\hline$U_{b}$ & Overall bottom loss coefficient, $\mathrm{W} / \mathrm{m}^{2}$ \\
\hline$U_{t}$ & Top loss coefficient, $\mathrm{W} / \mathrm{m}^{2}$ \\
\hline$U_{L}$ & Overall heat transfer coefficient, $\mathrm{W} / \mathrm{m}^{2}$ \\
\hline $\boldsymbol{K}$ & Thermal conductivity, W/mK \\
\hline$L, x$ & Thickness, $\mathrm{m}$ \\
\hline$l$ & Liquid \\
\hline$s$ & Solid \\
\hline$v$ & Wind speed, $\mathrm{m} / \mathrm{s}$ \\
\hline
\end{tabular}

\section{Greek Symbols}

$$
\begin{aligned}
& \alpha \\
& \alpha^{\prime} \\
& \varepsilon \\
& \delta \\
& \sigma \\
& \\
& \tau \\
& \eta_{i} \\
& \Delta T \\
& \gamma
\end{aligned}
$$$$
\Delta T
$$

\section{Subscripts}

$$
\begin{aligned}
& \mathrm{a} \\
& \mathrm{b} \\
& \mathrm{c} \\
& \text { cond } \\
& \mathrm{e} \\
& \text { eff } \\
& \boldsymbol{f} \\
& g \\
& \text { in } \\
& \text { ins } \\
& \boldsymbol{m} t
\end{aligned}
$$$$
\text { cond }
$$$$
\boldsymbol{o}
$$

\author{
Absorptivity \\ Fraction of solar energy absorbed \\ Emissivity \\ incremental rise, $\mathrm{K}$ \\ Stefan-Boltzmann constant, $\mathrm{W} / \mathrm{m}^{2}$ \\ $\mathrm{K}^{4}$ \\ 'Transmittance coefficient \\ Instantaneous efficiency (\%) \\ Effective temperature difference $(\mathrm{K})$ \\ Latent heat of vaporization $\mathrm{J} / \mathrm{kg}$
}

Ambient
Basin
Convective
Conduction
Evaporative
Effective
Film temperature
glass
inner
insulation
melting
outer

phase change material radiation water

\section{Appendix A}

The details of terms in eqs. :

$$
\begin{aligned}
& \mathrm{h}_{1}=\mathrm{h}_{\mathrm{cw}}+\mathrm{h}_{\mathrm{ew}}+\mathrm{h}_{\mathrm{rw}} \\
& \mathrm{h}_{\mathrm{cw}}=\mathrm{c} \mathrm{k} / \mathrm{k}_{\mathrm{f}} / \mathrm{Ra}^{\mathrm{n}} \\
& \mathrm{Ra}_{\mathrm{f}}=\mathrm{Gr}_{\mathrm{f}} \mathrm{pr}_{\mathrm{f}} \\
& \mathrm{Gr}_{\mathrm{f}}=\mathrm{d}^{3} \rho_{\mathrm{f}}^{2} \mathrm{~g} \beta \Delta \mathrm{T}^{\prime} / \mu_{\mathrm{f}}^{2} \\
& \Delta \mathrm{T}^{\prime}=\left[\left(\mathrm{T}_{\mathrm{w}}-\mathrm{T}_{\text {gin }}\right)+\left(\left(\mathrm{P}_{\mathrm{w}}-\mathrm{P}_{\text {gin }}\right)\left(\mathrm{T}_{\mathrm{w}}+273.15\right)\right) /\left(26800-\mathrm{P}_{\mathrm{w}}\right)\right] \\
& \text { \pr } \rrbracket_{-} \mathrm{f}=\left(\begin{array}{ll}
\mu_{\mathrm{f}} & \mathrm{C}_{\mathrm{f}}
\end{array}\right) / \mathrm{k}_{\mathrm{f}} \\
& \mathrm{P}_{\mathrm{w}}=\exp \left(\left(25.317-5144 /\left(\mathrm{T}_{\mathrm{w}}+273.15\right)\right)\right. \\
& \mathrm{P}_{\mathrm{gin}}=\exp \left(25.317-5144 /\left(\mathrm{T}_{\mathrm{gin}}+273.15\right)\right) \\
& \mathrm{h}_{\mathrm{ew}}=0.016273\left(\mathrm{~h}_{\mathrm{cw}}\left(\mathrm{P}_{\mathrm{w}}-\mathrm{P}_{\mathrm{gin}}\right) /\left(\mathrm{T}_{\mathrm{w}}-\mathrm{T}_{\mathrm{gin}}\right)\right) \\
& \mathrm{h}_{\mathrm{rw}}=\varepsilon_{\text {eff }} \sigma\left\{[ ( \mathrm { T } _ { \mathrm { w } } + 2 7 3 . 1 5 ) ^ { 2 } + ( \mathrm { T } _ { \mathrm { gin } } + 2 7 3 . 1 5 ) ^ { 2 } ] ^ { * } \left(\mathrm{T}_{-} \mathrm{w}-\right.\right. \\
& \mathrm{T} \operatorname{gin}+546)\} \\
& \varepsilon_{\text {eff }}=\rrbracket\left(1 / \varepsilon_{\mathrm{w}}+1 / \varepsilon_{\text {gin }}-1\right)^{-1} \\
& \mathrm{~h}_{2}=\mathrm{h}_{\mathrm{ca}}+\mathrm{h}_{\mathrm{ra}}=5.7+3.8 \mathrm{v}, \mathrm{v}=1 \mathrm{~m} / \mathrm{s} \\
& \mathrm{h}_{3}=0.54 \mathrm{k}_{\mathrm{w}} / \mathrm{x}_{\mathrm{c}} \mathrm{Ra}_{\mathrm{f}}{ }^{1 / 4}, \mathrm{Ra}_{\mathrm{f}}<8^{*} 10^{6} \\
& \mathrm{~h}_{3}=0.15 \mathrm{k}_{\mathrm{w}} / \mathrm{x}_{\mathrm{c}} \mathrm{Ra}_{\mathrm{f}}{ }^{1 / 4}, \mathrm{Ra}_{\mathrm{f}}>8 * 10^{6} \\
& \alpha_{\mathrm{g}}{ }^{\prime}=\alpha_{\mathrm{g}}\left(1-\mathrm{R}_{\mathrm{g}}\right) \\
& \alpha_{\mathrm{w}}^{\prime}=\alpha_{\mathrm{w}}\left(1-\alpha_{\mathrm{g}}\right)\left(1-\mathrm{R}_{\mathrm{g}}\right)\left(1-\mathrm{R}_{\mathrm{w}}\right) \\
& \alpha_{\mathrm{b}}{ }^{\prime}=\alpha_{\mathrm{b}}\left(1-\mathrm{R}_{\mathrm{g}}\right)\left(1-\alpha_{\mathrm{g}}\right)\left(1-\mathrm{R}_{\mathrm{w}}\right)\left(1-\alpha_{\mathrm{w}}\right) \\
& \mathrm{h}_{\mathrm{bc}}=\mathrm{L}_{\mathrm{b}} / \mathrm{k}_{\mathrm{b}} \\
& \mathrm{h}_{\mathrm{b}}=\left(\mathrm{L}_{\text {ins }} / \mathrm{k}_{\text {ins }}+1 / \mathrm{h}_{\mathrm{i}}\right)^{-1} \\
& \mathrm{U}_{\mathrm{L}}=\mathrm{U}_{\mathrm{t}}+\mathrm{U}_{\mathrm{b}} \quad, \mathrm{U}_{\mathrm{t}}=\mathrm{h}_{1} \mathrm{U}_{\mathrm{ga}} \quad /\left(\mathrm{h}_{1}+\mathrm{U}_{\mathrm{ga}}\right) \\
& \mathrm{U}_{\mathrm{b}}=\left(\mathrm{h}_{3} \mathrm{~h} \mathrm{~h}_{\mathrm{bc}}\right) /\left(\mathrm{h}_{3}+\mathrm{h}_{\mathrm{bc}}\right) \\
& \mathrm{U}_{\mathrm{ga}}=\left(\mathrm{k}_{\mathrm{g}} / \mathrm{L}_{\mathrm{g}} \mathrm{h}_{2}\right) /\left(\mathrm{K}_{\mathrm{g}} / \mathrm{L}_{\mathrm{g}}+\mathrm{h} \_2\right) \\
& \mathrm{A}_{\mathrm{eff}}=\alpha_{\mathrm{w}}{ }^{\prime}+\mathrm{U}_{1} \quad \alpha_{\mathrm{b}}{ }^{\prime}+\mathrm{U}_{2} \alpha_{\mathrm{g}}{ }^{\prime} \\
& \mathrm{U}_{1}=\mathrm{h}_{3} /\left(\mathrm{h}_{3}+\mathrm{h}_{\mathrm{b}}\right), \mathrm{U}_{2}=\mathrm{h}_{1} /\left(\mathrm{h}_{1}+\mathrm{U}_{\mathrm{ga}}\right)
\end{aligned}
$$

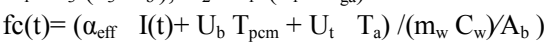

$$
\begin{aligned}
& f_{c} 1(t)=\left(\begin{array}{lll}
\alpha_{b}^{\prime} I(t) U_{3}+h_{b} & T_{a}+U_{b} & T_{w}
\end{array}\right) /\left(M_{\text {equ }} / A b\right) \\
& \mathrm{a}_{\mathrm{c}}=\left(\mathrm{U}_{\mathrm{L}} \mathrm{A}_{\mathrm{b}}\right) /\left(\mathrm{m}_{\mathrm{w}} \mathrm{C}_{\mathrm{w}}\right) \\
& \mathrm{a}_{\mathrm{cl}}=\left(\mathrm{U}_{\mathrm{b}}+\mathrm{h}_{\mathrm{bc}}\right) /\left(\mathrm{M}_{\mathrm{equ}} / \mathrm{A}_{\mathrm{b}}\right) \\
& \mathrm{U}_{3}=\mathrm{h}_{\mathrm{bc}} /\left(\mathrm{h}_{3}+\mathrm{h}_{\mathrm{bc}}\right) \\
& \left.\mathrm{fd}(\mathrm{t})=\left(\begin{array}{ll}
\mathrm{U}_{\mathrm{bd}} & \mathrm{T}_{\mathrm{pcm}}+\mathrm{U}_{\mathrm{t}} \mathrm{T}_{\mathrm{a}}
\end{array}\right) /\left(\mathrm{m}_{\mathrm{w}} \mathrm{C}_{\mathrm{w}}\right) \mathrm{A}_{\mathrm{b}}\right) \\
& a_{d}=\left(\begin{array}{ll}
U_{L d} & A_{b}
\end{array}\right) /\left(m_{w} C_{w}\right) \\
& \mathrm{U}_{\mathrm{Ld}}=\mathrm{U}_{\mathrm{t}}+\mathrm{U}_{\mathrm{bd}}, \mathrm{U}_{\mathrm{bd}}=\left(\mathrm{h}_{3} \mathrm{~h}_{\mathrm{bd}}\right) /\left(\mathrm{h}_{3}+\mathrm{h}_{\mathrm{bd}}\right) \\
& \mathrm{fd} 1(\mathrm{t})=\left(\begin{array}{lll}
-\mathrm{U}_{\mathrm{bd}} & \mathrm{T}_{\mathrm{w}}-\mathrm{h}_{\mathrm{b}} & \mathrm{Ta}
\end{array}\right) /\left(\mathrm{M}_{\text {equ }} / \mathrm{A}_{\mathrm{b}}\right)
\end{aligned}
$$

\section{REFERENCES}

[1] Bouchekima, B., A solar desalination plant for domestic water needs in arid areas of South Algeria Desalination 2002 153 p. $65-69$

[2] Shukla, S. K. and A. K. Rai, Analytical Thermal Modelling of Double Slope Solar Still by Using Inner Glass Cover temperature. Thermal Science, 2008. 12(3): p. 139-152

[3] Qiblawey, H. M., Fawzi Banat Solar thermal desalination technologies. Desalination, 2008. 220: p. 633-644

[4] Dwivedi V. k. and Tiwari G. N., Annual Energy and Exergy Analysis of Single and Double Slope Passive Solar Still, Trends in Applied Science Research, 2008. 3(3): p. 225-241

[5] Garg, H. P. and H. S. Mann, Effect of climatic, operational, and design parameters on the year round performance of single-sloped and double-sloped solar still under Indian arid zone conditions. Journal Name: Sol. Energy; (United States); 
Journal Volume: 18:2, 1976: p. Medium: X; Size: Pages: $159-164$

[6] Fath, H., Solar distillation: a promising alternative for water provision with free energy, a simple technology and a clean environment. , Desalination, 1998. 116 p. 45-56

[7] Anil K, R., Effect of various dyes on solar distillation. Solar Energy, 1981. 27(1): p. 51-65

[8] Singh, H. N. and G. N. Tiwari, Monthly performance of passive and active solar stills for different Indian climatic conditions. Desalination, 2004. 168(0): p. 145-150

[9] Dev, R. and G. N. Tiwari, Characteristic equation of a passive solar still. Desalination, 2009. 245(1-3): p. 246-265

[10] Akash, B. A., et al., Experimental evaluation of a single-basin solar still using different absorbing materials. Renewable Energy, 1998. 14(1-4): p. 307-310

[11] Nafey, A. S., et al., Enhancement of solar still productivity using floating perforated black plate. Energy Conversion and Management, 2002. 43(7): p. 937-946

[12] Shukla, S. K. and V. P. S. Sorayan, Thermal modeling of solar stills: An experimental validation: Renewable Energy. Fuel and Energy Abstracts, 2005. 30(5): p. 683-699

[13] Agyenim, F., et al., A review of materials, heat transfer and phase change problem formulation for latent heat thermal energy storage systems (LHTESS). Renewable and Sustainable Energy Reviews, 2010. 14(2): p. 615-628

[14] Abdulhaiy, M. R., Transient performance of a stepped solar still withbuilt-in latent heat thermal energy storage. Desalination, 2005. 171(1): p. 61-76

[15] El-Sebaii, A. A., et al., Thermal performance of a single basin solar still with PCM as a storage medium. Applied Energy, 2009. 86(7-8): p. 1187-1195

[16] Sarı, S., Thermal reliability test of some fatty acids as PCMs used for solar thermal latent heat storage applications. Energy Conversion and Management, 2003. 44(14): p. 2277-2287

[17] Sar1, A. and K. Kaygusuz, Thermal and heat transfer characteristics in a latent heat storage system using lauric acid. Energy Conversion and Management, 2002. 43(18): p. 2493-2507

[18] Sharma Dutt, Kitano Hiroaki, and Sagara Kazunobu, Phase Change Materials for Low Temperature Solar Thermal Applications. Res. Rep. Fac. Eng. Mie Univ., 2004. 29: p. 31-64

[19] Buddhi D, et al., A simplification of the differential thermal analysis method to determine the latent heat of fusion of phase change materials. J. Phys. D: Appl. Phys., 198720 p. 1601 